\title{
Psychological determinants of manifestation of a person's creativity at the stage of higher education
}

\author{
Valentina Viktorovna Grebneva ${ }^{1 *}$, Svetlana Anatolievna Korneeva ${ }^{1}$, Lyudmila Borisovna \\ Kuznetsova $^{1}$, Oksana Sergeevna Miroshnikova ${ }^{1}$, and Svetlana Valeryevna Moskalenko ${ }^{1}$ \\ ${ }^{1}$ Belgorod National Research University, Psychologycal Department, Faculty of Psychology \\ Pedagogical Institute, Belgorod, Russia
}

\begin{abstract}
Despite the significance and effectiveness of numerous studies, the role and relationship of internal (psychological) and external (environmental) factors in the development of creativity at the stage of studying at a university are not clearly determined. The conducted study aims to analyze the psychological prerequisites for the development of a person's creativity at student age. The study tests the hypothesis that students demonstrating a higher level of creativity have several individual psychological features including genetically predetermined ones. The deployed psychodiagnostic methods include the "creativity" scale of the Self-actualization diagnostic questionnaire "SAMOAL" (A.V. Lazukina, as adapted by N.F. Kalin), "Questionnaire for diagnostics of the dominating instinct" (V.I. Garbuzov); the Eysenck Personality Inventory (EPI), and "The method of diagnostics of the learning style parameters" (A. Soloman, R. Felder). The obtained results provide for a more precise description of the psychological portrait of a student with high creativity level as well as indicate the presence of genetically predetermined factors of predisposition to the development of creativity as a creative attitude towards life.
\end{abstract}

Keywords: creativity, individual psychological characteristics, student age.

\section{Introduction}

The changes taking place in the modern world and the multitasking nature of the professional activity of a modern person call for the development of such a personal characteristic of a future specialist as creativity.

Creativity is viewed as a person's innovative readiness for changes and firmly associated with "social and economic progress" [1:3]. There are two main directions of interpretation of the content of creativity as a concept: creativity as a cognitive process and creativity as a creative attitude towards life [2: 292].

\footnotetext{
*Corresponding author: grebneva@bsu.edu.ru
} 
Many researchers believe that there are natural foundations of a person's creativity lying in the structure of instincts and needs. According to C.G. Jung, “...human activity is significantly influenced by instincts completely independent of the rational motivation of consciousness" [3: 73]. Creativity as a factor of a person's activity and behavior also presents a biological resource (instinct) modified within the structure of personality by means of individual characteristics of the psyche [4]. Modern studies on human needs are nothing less than "the great rehabilitation of instincts" [5]. V.I. Garbuzov distinguishes between the "feminine" (female) and "masculine" (male) groups of needs [6]. Examining needs in the context of creativity research, we hypothesize that there is a positive relationship between the creative nature of the psyche and the masculine needs of an individual.

Among the factors of manifestation of creativity, some authors consider the peculiarities of self-awareness of the individual.

According to O.N. Molchanova's research [7], self-esteem can be viewed as a generalized affective evaluation of the Self or as a sum of evaluation of specific characteristics. Several studies indicate that people with low self-esteem prefer positive feedback at the emotional level and negative feedback at the cognitive level [8]. The author states that this association is largely characteristic of people with high creativity levels which is especially valuable from the point of our study.

E.M. Pavlova motes that the problem of the relationship between self-esteem and success in creative activity is based not only on the phenomena of the functioning of selfesteem but also on the ambiguity of criteria for evaluating the relevant activities and the underestimation of their particular types in terms of the possibility of manifestation of the creative potential of the individual [9].

The degree to which self-esteem reflects the objective level of development of creative abilities is a matter of debate, among other things, regarding creativity. Research on selfesteem in different spheres often reveals its low or significant correlation with objective measures of creativity $[10,11]$.

I.V. Fokina indicates that in its nature, creativity is in one way or another related to the specifics of human contact with the environment [12]. In psychological science, the specifics of interaction with the environment are most often defined by the concepts of extraversion and introversion.

The individual style of activity can also be considered an internal factor of creativity development. The individual style of activity describes the way a person uses certain personal qualities to obtain the necessary result [13]. According to some data, the individual style of activity has a determining influence on personality development precisely at the adolescent age [14].

Thus, despite the relevance of the problem of purposeful development of creativity in future professionals, the issue of psychological factors in the development of creativity is still under debate [15-17].

The purpose of our empirical study is to analyze the psychological prerequisites for the development of a person's creativity at a student age.

We hypothesize that students demonstrating a higher level of creativity have several individual psychological features including genetically predetermined ones.

\section{Methods}

The study was conducted based on the Belgorod State National Research University. The study sample includes first-year students of the Faculty of Mathematics and Science Education. The total number of respondents is 58 .

The developed study design is presented in Table 1. 
Table 1. Parameters of the analysis of the relationship between individual-typological features of students and their creativity level and the deployed psychodiagnostic methods

\begin{tabular}{|l|l|}
\hline \multicolumn{1}{|c|}{ Diagnosed parameter } & \multicolumn{1}{c|}{ Psychodiagnostic methods } \\
\hline 1. Creativity level & $\begin{array}{l}\text { The "creativity" scale of the SAMOAL personality self- } \\
\text { actualization diagnostic questionnaire (A.V. Lazukina, as } \\
\text { adapted by N.F. Kalin) }\end{array}$ \\
\hline $\begin{array}{l}\text { 2. Individual-typological } \\
\text { features of personality }\end{array}$ & $\begin{array}{l}\text {-"Questionnaire for diagnostics of the dominating instinct" (V. } \\
\text { I. Garbuzov); } \\
\text { - the Eysenck's Personality Inventory (EPI) }\end{array}$ \\
\hline $\begin{array}{l}\text { 3. Characteristics of the self- } \\
\text { concept }\end{array}$ & $\begin{array}{l}\text { "Method for the study of self-esteem" (T.V. Dembo, S.Ia. } \\
\text { Rubinstein) }\end{array}$ \\
\hline $\begin{array}{l}\text { 4. Characteristics of individual } \\
\text { style of activity }\end{array}$ & $\begin{array}{l}\text { "The method of diagnostics of the learning style parameters" } \\
\text { (A. Soloman, R. Felder) }\end{array}$ \\
\hline
\end{tabular}

Statistical analysis of the obtained data is performed using Pearson's $r$ correlation criterion.

\section{Results}

We proceed to the consideration of the obtained results, their interpretation, and analysis. Figure 1 shows the distribution of the sample of subjects by the levels of creativity.

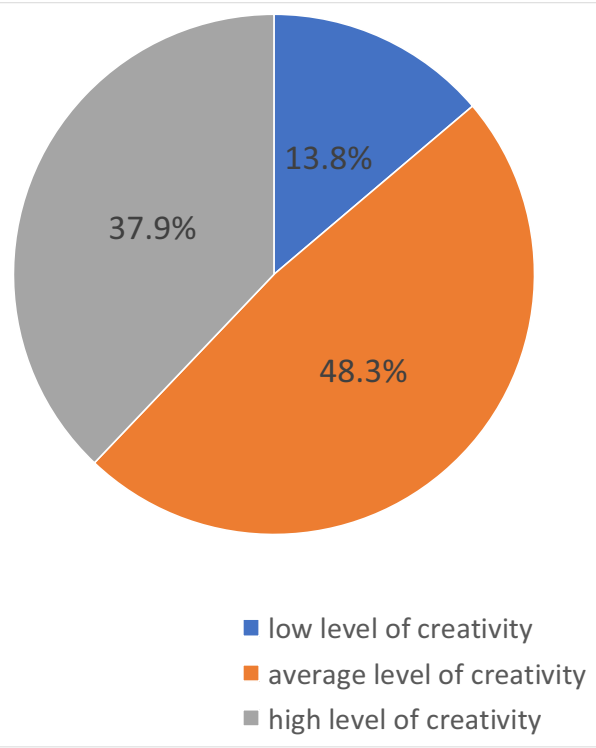

Fig. 1. The ratio of students with different levels of creativity (in \%).

The analysis of the obtained data demonstrates that the groups of students with an average level of creativity (48.3\%) and a high level of creativity (37.9\%) are the most represented in the sample. The group of students demonstrating a low level of creativity is represented insignificantly $(13.8 \%)$. Thus, we conclude that the creativity of the respondents is mostly within the medium and high levels.

The main objective of the study is to reveal the individual psychological prerequisites for creativity development. To meet this task, we analyze the correlation between the psychological "portrait" of the respondents and their creativity level (Table 2). 
Table 2. Pearson's r correlation coefficients between creativity level and the students' individual psychological characteristics.

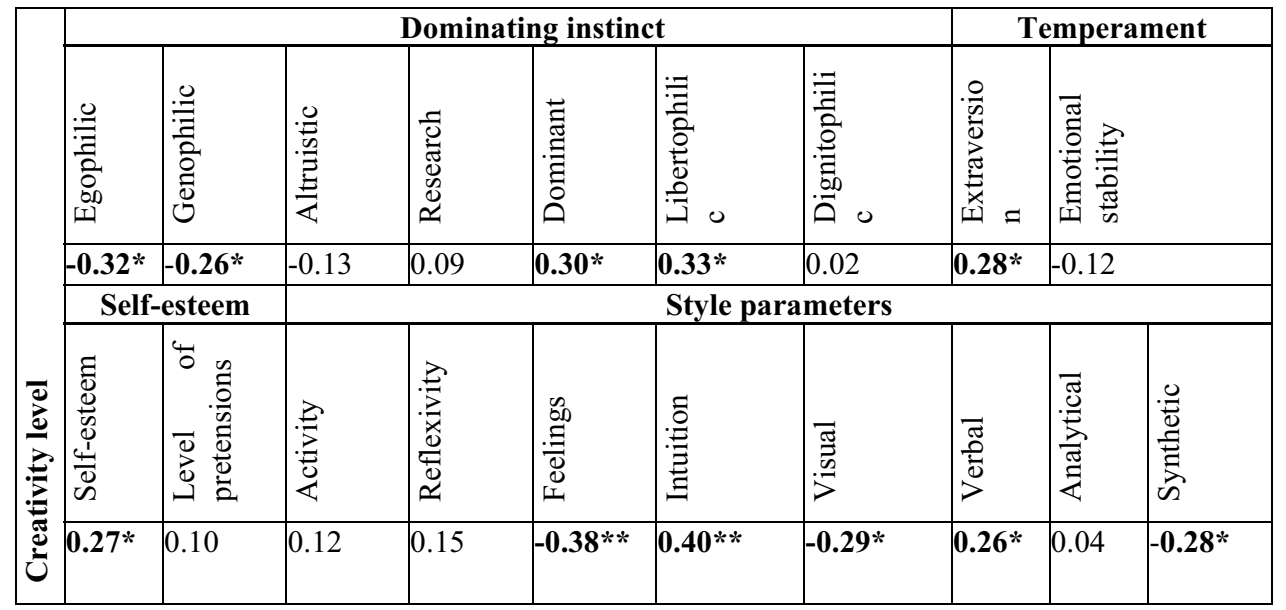

Note: * - significance level $p \leq 0.05 ; * *$ - significance level $p \leq 0.01$.

A positive correlation is found between the level of creativity and characteristics of temperament. The propensity for Internet addiction positively correlates with extraversion $(\mathrm{r}=0.28, \mathrm{p} \leq 0.05)$. Thus, students with a high level of creativity can be characterized as individuals inclined to active social contacts, external expression of feelings, emotions, and thoughts, and capable of revealing their talents to a greater extent only in interaction with the outside world.

The study shows that creativity is associated with the dominating instincts (genetically predetermined basic life needs). In particular, inverse correlations are found between creativity and the egophilic $(r=-0.32, p \leq 0.05)$ and genophilic $(r=-0.26, p \leq 0.05)$ instincts.

Direct correlations are found between the level of creativity and such dominating instincts as the dominant $(\mathrm{r}=-0.30, \mathrm{p} \leq 0.05)$ and the libertophilic $(\mathrm{r}=-0.33, \mathrm{p} \leq 0.05)$. It should be noted that both of these instincts represent the masculine group of needs the main characteristic of which is the tendency to move, to get out of the "comfort zone". This supports the proposed assumption that there is a positive connection between the creative nature of the psyche and the masculine needs of an individual.

The analysis of the relationship between creativity and self-esteem of students also reveals a significant correlation. There is a direct correlation between the level of creativity and the level of self-esteem $(\mathrm{r}=0.27, \mathrm{p} \leq 0.05)$. Thus, students with pronounced creativity considered as a creative attitude towards life in the context of self-actualization tend to evaluate themselves and the results of their activities more highly.

The most significant correlations are found between creativity and learning style parameters. Creativity positively correlates with intuition $(\mathrm{r}=0.40, \mathrm{p} \leq 0.01)$ and the verbal learning style $(\mathrm{r}=0.26, \mathrm{p} \leq 0.05)$. Inverse correlations are found between creativity indicators and the style parameters of feelings $(r=-0.38, p \leq 0.01)$, the visual learning style $(r=-0.29$, $\mathrm{p} \leq 0.05)$, and the synthetic learning style $(\mathrm{r}=-0.28, \mathrm{p} \leq 0.05)$. Summarizing the obtained results, the peculiarities of the individual learning style of a student with a high level of creativity can be characterized as follows: these students are more prone to uncertainty and recognizing abstract patterns and perceive and assimilate educational material more effectively in the process of communication.

Thus, the parameters that can be considered the style-related prerequisites of creativity are 1) the tendency to obtain information in interaction and communication and discussion and 2) the activation of cognitive activity in situations of uncertainty. 


\section{Discussion}

The results we obtained are consistent with the research of E.M. Pavlova and T.V. Kornilova showing that creativity assessed through the "Creative headings" method is directly associated with the self-assessment of creativity and trust in intuition $[11,18]$.

According to the results obtained by E.M. Pavlova, the self-assessment of creativity and intelligence is based on both the processes of acceptance of uncertainty and specific achievements in creative activity [9].

The data obtained by us on student respondents contradicts the data of research in a group of schoolchildren at the stage of transition from primary to secondary school. Children with high creativity become the so-called risk group in terms of psychological well-being with a high degree of probability [19].

Examining the interrelation and interdependence of self-esteem and creativity of a person, O.N. Molchanova identifies two groups of the most essential factors: the subject's achievements in various activities and the attitude of other people.

S. Harter provides empirical evidence of the fact that these two factors determining selfesteem work in association: the greater are the achievements in important areas and the higher is social support, the higher is self-respect [20].

\section{Conclusion}

Overall, based on the results of the conducted study, we can draw the following main conclusions:

1. The obtained results provide for a clearer description of the psychological portrait of a student with a high level of creativity as well as allow stating that there are genetically predetermined factors of predisposition to the development of creativity as a creative attitude towards life.

2. Characterizing the psychological portrait of a student with a high level of creativity, we can identify several psychological features: an inclination towards active social contacts, the external manifestation of feelings, emotions, thoughts, and abilities, and a pronounced manifestation of the masculine genetically predetermined needs.

3. Based on the identified peculiarities of the psychological portrait of a student with a high level of creative ability, we can conclude on the presence of external (environmental) prerequisites for the development of creativity in the conditions of the educational process of a modern university.

\section{References}

1. D.V. Ushakov (Ed.), Tvorchestvo: ot biologicheskikh osnovanii k sotsialnym i kulturnym fenomenam [Creativity: from biological foundations to social and cultural phenomena] (Institute of Psychology of the Russian Academy of Sciences, Moscow, 2017)

2. M.G. Iurkova, Kreativnost lichnosti kak faktor formirovaniia obraza professii kak komponenta professionalnogo samosoznaniia $v$ period obucheniia $v$ vuze [Creativity of a person as a factor in the formation of the image of the profession as a component of professional self-awareness in the period of study at the university], in Social and psychological problems of modern education. Materials of the All-Russian Scientific and Practical Conference 2018, Irkutsk, Russia, 290-299 (2018)

3. C.G. Jung, Struktura psikhiki i protsess individuatsii [The structure of the psyche and the process of individuation] (Nauka, Moscow, 2016) 
4. J. Hillman, Arhetipicheskaia psikhologiia, Seriia: Iungianskaia psikhologiia [Archetypal Psychology, Series: Jungian Psychology] (Kogito-Tsentr, Moscow, 2006)

5. V.I. Garbuzov, Chelovek - zhizn - zdorove (Drevnie i novye kanony meditsiny) [Man - Life - Health (Ancient and new canons of medicine)], 2nd ed. (Komplekt JSC, Saint Petersburg, 1995)

6. V.V. Grebneva, Belgorod State University Scientific Bulletin. Series: Humanities, 14(263), 180-190 (2017)

7. O.N. Molchanova, Kulturno-istoricheskaya Psikhologiya [Cultural-Historical Psychology], 6(3), 67-77 (2010)

8. L.V. Smolova, Ekologicheskaia psikhologiia [Ecological Psychology], 2nd ed. (Iurait Publishing House, Moscow, 2020)

9. E.M. Pavlova, Psychology. Journal of the Higher School of Economics, 15(1), 69-78 (2018)

10. T.V. Kornilova, Intellektualno-lichnostnyi potentsial cheloveka v usloviiakh neopredelennosti i riska [Intellectual and personality potential of a person under conditions of uncertainty and risk] (Nestor-Istoriia, Saint Petersburg, 2016)

11. E.M. Pavlova, T.V. Kornilova, The "Positive Triad" of the regulation of personal choice among creative professionals, in G.B. Moneta, E. Rogaten (Eds.), Psychology of Creativity, 153-166 (Nova Science Publishers, New York, 2016)

12. I.V. Fokina, Perspektivy nauki i obrazovaniia, 6, 161-172 (2013)

13. M.A. Pakhmutova, Individualnye stili issledovatelskoi deiatelnosti studentov: deiatelnostnyi i lichnostnyi aspekt [Individual styles of students' research activity: activity and personality aspects], in Education and Teacher in the Information Society: a View from the Future. Materials of the All-Russian Scientific-Practical Conference with International Participation, 22 November 2016, Ussuriysk, Russia, 142-144 (2016)

14. A.P.Lobanov, N.V. Drozdova, Journal of the Belarusian State University. Philosophy. Psychology, 2, 108-113 (2020)

15. M. Galton, Research Papers in Education, 25(4), 355-375 (2010)

16. M. Drus, M. Drus, A. Kozbelt, R. R. Hughes, Creativity Research Journal, 26(3), 251262 (2014)

17. A. Peña-Sarrionandia, M. Mikolajczak, J.J. Gross, Frontiers in Psychology, 6(160), 127 (2015)

18. E.M. Pavlova, T.V. Kornilova, Psikhologo-pedagogicheskie issledovaniia, 11(1), 107117 (2019)

19. N.B. Shumakova, N.I. Avdeeva, E.V. Klimanova, Razvitiye issledovatelskikh umeniy mladshikh shkolnikov [Development of research skills of primary schoolchildren] (Prosveshchenie, Moscow, 2011)

20. S. Harter, Development processes in the construction of the self, in T.D. Yawkey, J.E. Johnson (Eds.), Integrative Processes in Socialization: Early to Middle Childhood (Erlbaum, Hillsdale, NJ, 2008) 